\title{
STIGMA OF COVID-19 ON ECONOMIC ACTIVITIES: A CASE STUDY OF SHEIN IN MEXICO
}

\author{
Sunday Adewale Olaleye ${ }^{1}$, Oluwaseun Alexander Dada ${ }^{2}$, Josue Kuika Watat ${ }^{3}$ \\ and Richard O. Agjei ${ }^{4}$ \\ ${ }^{1}$ Oulu Business School, Department of Marketing, Management and International Business, University of Oulu, \\ Erkki Koiso-Kanttilan katu, 90570 Oulu, Finland \\ ${ }^{2}$ Institute for Molecular Medicine Finland (FIMM), University of Helsinki, Biomedicum 2U, 00290 Helsinki, Finland \\ ${ }^{3}$ Digital Advisor at AMBERO Consulting GmbH, P.O BOX 11632, Ekounou-Ayene, Yaounde, Cameroon \\ ${ }^{4}$ Dr., University of Central Nicaragua Medical Center, Department of Public Health, Semaforos del Zumen 3C, \\ Nicaragua
}

\begin{abstract}
During the economic crisis due to a virus called COVID-19, different countries were affected worldwide, and several micro and macro companies have been affected because they had to temporarily close their business platform or experience a decrease in their sales. The conflict has reached Mexico, causing a voluntary quarantine. Mexicans' perception of China has worsened because of the pandemic. International companies from China are affected by their operations. This store has a decrease in sales due to a bad perception of Chinese products by Mexicans. This research embarked on quantitative methodology with descriptive statistics, correlation and ANOVA through SPSS version 26 to answer the arising research questions. The results show a mixed feeling of the buyers. Some customers wish to continue to patronize e-commerce while others wish to disassociate themselves with the e-commerce platform due to the stigma of the country of origin. This finding reveals that there is a tendency for the e-commerce platform to lose some of its customers. This study contributes to the literature of stigma theoretically and managerially. The managerial contribution will help SHEIN to regain their lost reputation and other companies that suffers from COVID-19 stigmatization.
\end{abstract}

\section{KEYWORDS}

Stigma, COVID-19, Economic Activities, SHEIN, Mexico

\section{INTRODUCTION}

During the economic crisis due to a virus called COVID-19, different countries were affected worldwide, and several micro and macro companies have been affected because they had to temporarily close their business platform or experience a decrease in their sales. Such huge loss in revenue and decrease in profit margins since the emergence of the COVID-19 pandemic have been widely reported across the globe (Carlsson-Szlezak et al. 2020; The Economist 2020; Ayittey et al. 2020; O'Sullivan 2020; Weller 2020). Surprisingly, studies conducted by Trautmann et al., (2016) had forecasted about 16.3 trillion U.S dollars economic loss worldwide between the period of 2010-2030 even before the emergence of havoc-recking COVID-19 pandemic.

Today the world has been affected by this pandemic, which started in Wuhan, China. According to TrackCorona today (01.01.2021), there are 83,957,807 confirmed cases, 58,898,568 recovered and 1,829,048 deaths. These account for $2.18 \%$ fatality rate and $70.15 \%$ recovery rate. The conflict has reached Mexico, causing a voluntary quarantine. Mexicans' perception of China has worsened because of the pandemic. International companies in China are affected by their operations. According to reports from the main e-commerce rankings, SHEIN is the third most preferred e-commerce company by Mexicans. This store has a decrease in sales due to a bad perception of Chinese products by Mexicans.

COVID-19 is like a taproot that characterizes largeness, centrality with a domineering root which accommodates other roots laterally. Stigma is one of the offshoots of COVID-19, and it is a state of extreme disgrace or dishonor. It is a weapon of defense, anger, and fear. It is an effect of uncertainty and has ripple effects of tribalism, disassociation, and violence. According to UNICEF, "social stigma in the context of health is the negative association between a person or group of people who share certain characteristics and a specific disease," COVID-19 source of stigma can be traced to the novelty of the disease, the fear of unknown and transferred aggression of the fear with others (UNICEF, 2020). 
Stigma has become a global issue, and there are debates on stigmatization in different perspectives; for example, Andrade, (2020) dwells on medical conspiracy theories and emphasized the support of majorities Americans over the minorities of other races based on stigmatization issue. The author tends to say that the majority favor the government in response to stigmatization than the minority. Moufakkir (2015) also discussed the stigmatization of the tourists to the developed country and mentioned that the tourists are stigmatized by reckoning with their homeland. Estadilla (2020) accused the global government of having created a pandemic of stigmatization and discrimination.

These earlier studies focused on the stigmatization of the COVID-19 patients, health workers, governments, and the highly risky countries of COVID-19. Despite the impact of these studies, we are yet to have a full understanding of how stigmatization affects the economic activities of e-commerce platforms. This study intends to shed light on unanswered questions of e-commerce stigmatization. The following research questions will proffer solution to the hanging issues of stigmatization. 1) What is the connection between COVID-19 and economic activities, and why is it essential to examine their curvilinear relationship? 2) How is COVID-19 stigmatization affecting the economic activities of e-commerce, and how can they overcome the lingering situation?

This research embarked on quantitative methodology with descriptive statistics, correlation and ANOVA through SPSS version 26 to answer these research questions. The results show a mixed feeling of the buyers. Some customers wish to continue to patronize e-commerce while others wish to disassociate themselves with the e-commerce platform due to the stigma of the country of origin. This finding reveals that there is a tendency for the e-commerce platform to lose some of its customers, and if loyal customers constitute the group that chooses to churn due to the stigmatization, it will have many consequences on the e-commerce chain. It will affect their revenue and their increasing customer's loyalty. This study proceeds with the introduction, then switch to the discussion of important and relevant literature with a focus on Goffman's Theory of Social Stigma. The third part discusses the methodology adopted for this study, while the fourth part presents and discusses the results. The next part explains the theoretical and managerial implications and finally discusses the study limitation and make some proposals for future study.

\subsection{Case Company Background}

The low-cost business model that serves as a point of attraction to the Mexicans, the fashion sector, being the third-largest e-commerce in Mexico, and the Chinese origin motivates the choice of this company. SHEIN is an intercontinental B2C fast fashion e-commerce platform in more than 220 countries. This e-commerce organization focused more on America, Australia, Europe, and the Middle East and opened its brand in 2008. The philosophy of SHEIN is that "everyone can enjoy the beauty of fashion" and its mission to provide trending styles offering for women and teens while men and the kids were not left out.

\section{LITERATURE REVIEW}

A stigma may be defined as a deeply discredited characteristic that links an entity to an undesirable stereotype (Goffman, 1963). The entity can be a person or an organisation. As a construct, stigma often leads to social and economic inequality. In their work, Parker and Aggleton (2003) investigated 'how stigma is used by individuals, communities and the state to produce and reproduce social inequality'. Several publications on stigma were targeted at individuals with health problems. For instance, Odindo and Mwanthi (2008) studied the role of organizations in mitigation of stigma and discrimination of HIV/AIDS victims. In the same vein, there are research articles on organisational stigma. Devers, Dewett, and Belsito (2005) combined stigma theory with the organizational reputation in their quest to understand the external factors cause and sustain organizational stigma. Tracey and Phillips (2016) examined a case of an organisation that was stigmatized due to its support for immigrants in the East of England.

Many stigma studies are often situated in the context of 'prejudice'. Allport $(1954$, p. 7$)$ defines prejudice as an unfriendly attitude toward an entity which belongs to a particular category, simply because it belongs to that category, and is therefore presumed to have the unpleasant characteristics ascribed to the category". In essence, stigmatized people or organisations are often 'label' based on certain ideologies or perceptions - and henceforth prejudices against. Studies have shown that organisational stigma has negative consequence on the 
how consumers perceive its products (Correia de Barros, Duarte and Cruz, 2011) - and ultimately on product sales. Ahmad (2018) and Bashir et al. (2013) explored the online buying behavior of a group of undergraduate students, they found that some of the most important influencing factors were trust, firm reputation, and safety of the products.

To demystify how stigma is propagated, Meisenbach (2010) suggested three maxims on the methodological approach to stigmatization. First, the stigmas are rationally structured referring to the impressions of non-stigmatized people and even those stigmatized. It thus provides information on the scope of stigmatization not only according to an identity but perceived exclusively by the stigmatized individual or the community. Second, stigmatized people are vulnerable because they are subject to dynamic exogenous factors and have strong consequences on stigmatized identity (Meisenbach, 2010). Thirdly, the stigmas are unique and therefore lead to a need to understand the categories of stigmas but also the level of stigma according to identities (Meisenbach, 2010). Taking inspiration from Pryor and Reeder (2011), we present a stigma framework for economic activities as illustrated in Figure 1. The model examines the interwovenness of structural stigma, public stigma, stigma by association and self-stigma as factors of consideration for organization dent reputation and organization response to COVID-19 stigma. SHEIN is an e-commerce company that originates from China starts from structural stigma and degenerate to public stigma and to stigma by association that affect the global of brand of SHEIN and diffuse to self-stigma of SHEIN workers. The four types of stigma have dented the reputation of SHEIN and it requires an urgent image laundry measures (Figure 1).

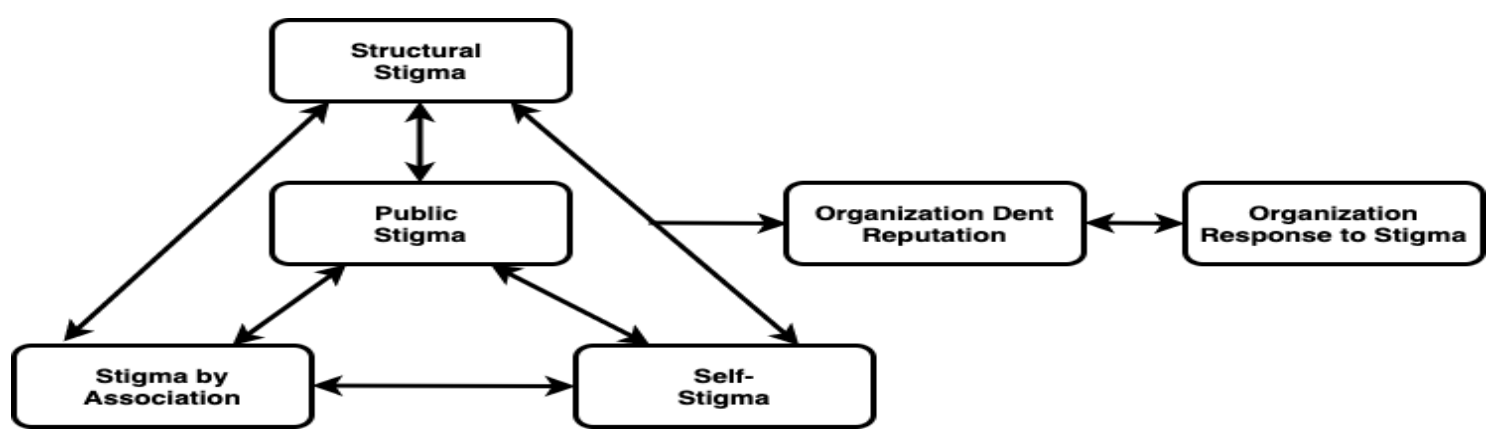

Figure 1. Stigma Framework for Economic Activities

\section{METHODOLOGY FOR STIGMA STUDY}

The study used a quantitative method to seek e-commerce customers' opinion on stigmatization and how it affects online transactions during the COVID-19. The study used convenience sampling and focused on University students. The choice for students is due to their online stability. Specifically, this study focused on Bachelor students with age brackets 15 to 25 due to their availability at the time of the data gathering and COVID-19 disruption. This student segment shares similar characteristics and interests in online shopping.

Similarly, early researchers have used students' sample (Bartneck, Duenser, Moltchanova., and Zawieska, 2015; Faqih and Jaradat, 2015; Stokes and Senkbeil, 2017; Olaleye, Salo, Sanusi and Okunoye, 2018). This student sample used is a combination of Gen Z and Millennials, and they are prone to digital tools. An online survey was conducted to unveil the customers' bad perception regarding SHEIN brand and their belief that the packages they order in SHEIN are infected with the virus, which is a little bit controversial. Considering the above misconstrues, this study utilized descriptive statistics and Likert scale questions to investigate the stigmatization of SHEIN brand and online relationship with its customers during COVID-19. The study used SPSS ver. 26 to analyze the data with correlation, and ANOVA, data analysis techniques.

\subsection{Data Collection Procedure for Stigma Study}

The study designed 15 descriptive and Likert scale questions that captures the profile of SHEIN online customers and stigmatization thoughts such as gender, age, online purchases, affiliation with SHEIN and the impact of COVID-19 on SHEIN online store. 83 students of Universidad de las Americas Puebla, Mexico that are familiar with SHEIN online purchases participated in the study through online Google Form between January and April 2020. 


\subsection{Descriptive Statistics for Stigma Study}

Figure 2 shows the descriptive statistics for this study. $47(57 \%)$ female students participated in the study and $36(43 \%)$ of male students. The study compared the participants gender and different age brackets. For age brackets $15-17$, two male students and 1 female student participated. Regarding age brackets $18-21,13$ male students and 26 female students shown their opinion concerning online shopping stigmatization while age brackets $22-25$ shows that 21 male students and 20 female students actively involved in the online stigma survey. Also, in Figure 3, 59 respondents indicate that they are aware that SHEIN origin is from China while 24 respondents are ignorant of SHEIN origin.

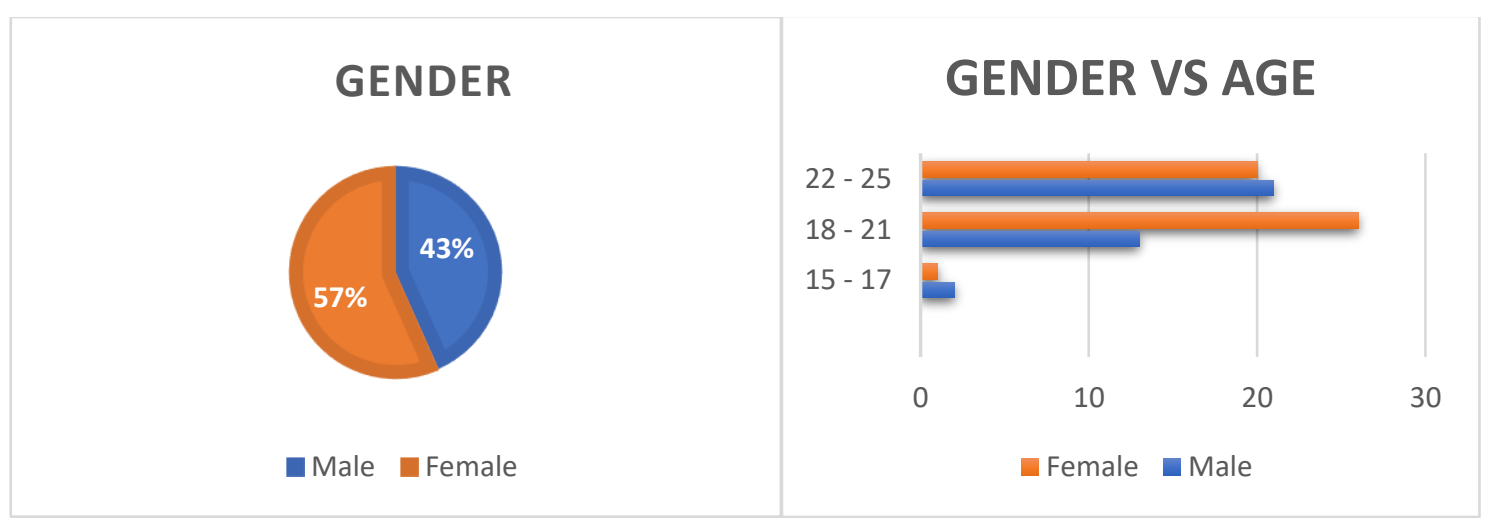

Figure 2. Gender vs Age Statistics

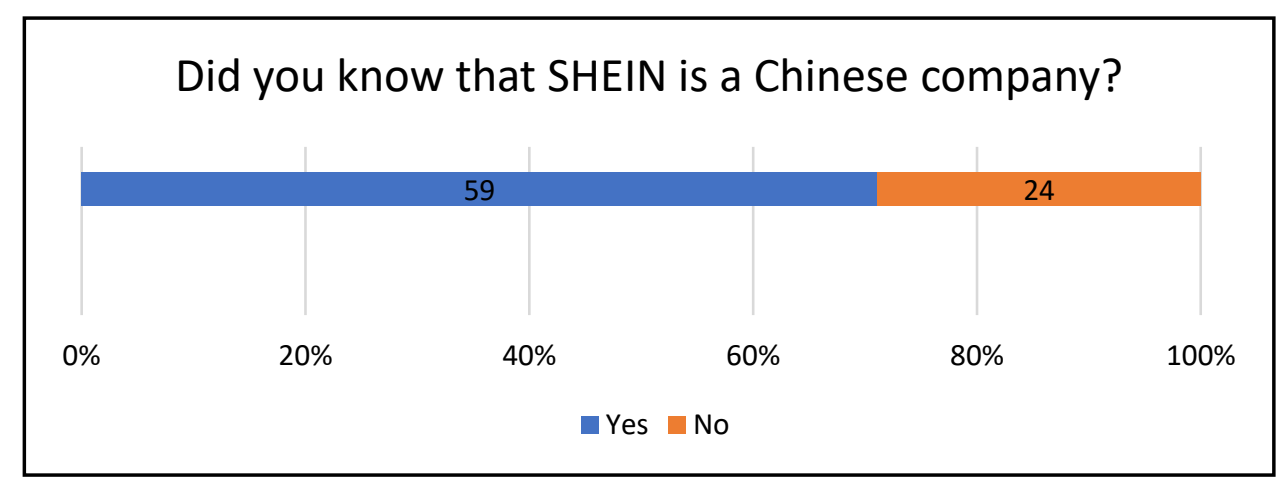

Figure 3. SHEIN Background

Table 1. Descriptive statistics and five Likert Scale

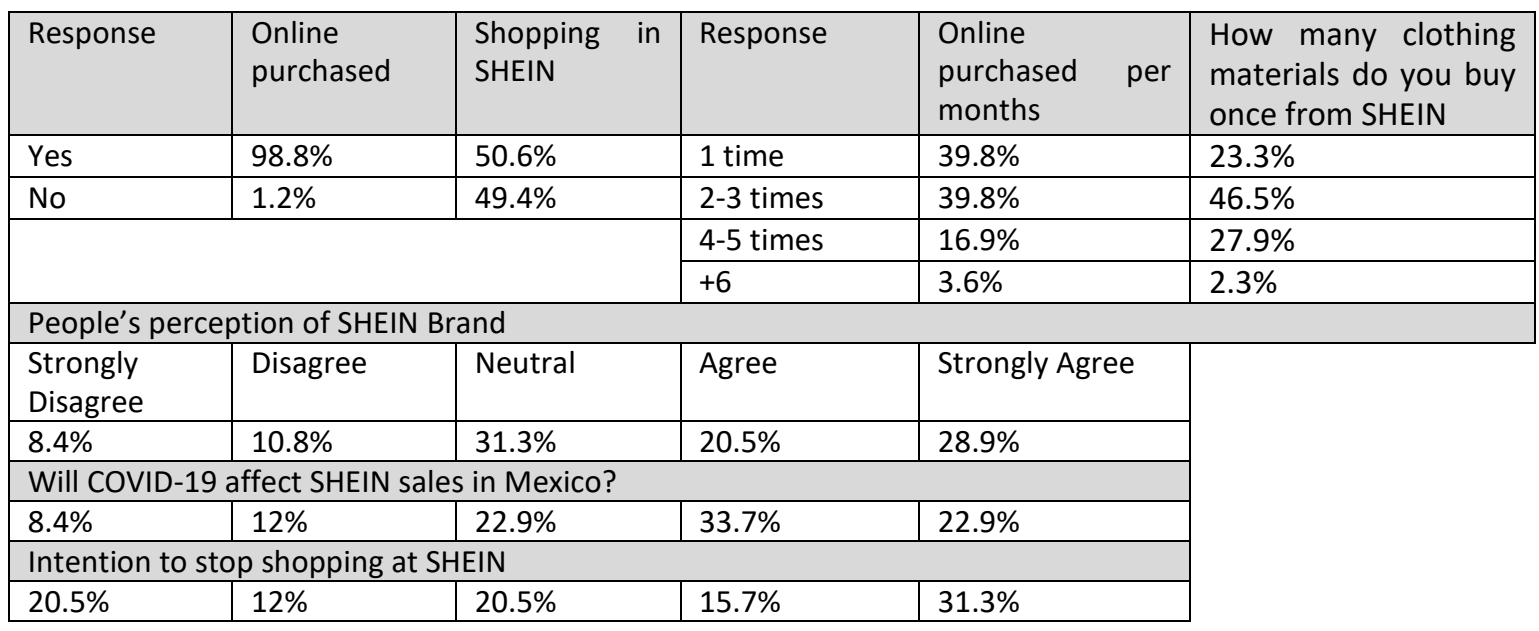


Table 2. Correlation of Variables

\begin{tabular}{|c|c|c|c|}
\hline Variables & SHEIN Perception & SHEIN Clothes Like & SHEIN Sales \\
\hline \multirow{3}{*}{$\begin{array}{l}\text { SHEIN perception can be } \\
\text { affected by COVID- } 19 \text {. }\end{array}$} & Pearson Correlation & -.026 & $-.624 * *$ \\
\hline & Sig. (2-tailed) & .814 & .000 \\
\hline & $\mathrm{N}$ & 83 & 83 \\
\hline \multirow{3}{*}{$\begin{array}{l}\text { Do you still like SHEIN } \\
\text { clothes during COVID-19. }\end{array}$} & Pearson Correlation & 1 & .049 \\
\hline & Sig. (2-tailed) & & .659 \\
\hline & $\mathrm{N}$ & 83 & 83 \\
\hline \multirow{3}{*}{$\begin{array}{l}\text { SHEIN sales can be affected } \\
\text { by COVID- } 19 \text {. }\end{array}$} & Pearson Correlation $-.624 * *$ & .049 & \multirow{2}{*}{1} \\
\hline & $\begin{array}{ll}\text { Sig. (2-tailed) } & .000\end{array}$ & .659 & \\
\hline & $\mathrm{N}$ & 83 & 83 \\
\hline \multirow{3}{*}{$\begin{array}{l}\text { Buyers can stop buying from } \\
\text { SHEIN because of COVID- } \\
19 \text {. }\end{array}$} & Pearson Correlation & $-.344 * *$ & .036 \\
\hline & Sig. (2-tailed) & .001 & .750 \\
\hline & $\mathrm{N}$ & 83 & 83 \\
\hline
\end{tabular}

\section{RESULTS}

The beginning and the spread of Corona Virus from China has gone beyond political, social and religious issues. The impact of COVID-19 on China as a country has degenerates into stigmatization that is negatively affecting the economic situation of Chinese outlets globally. The Chinese companies now wear an outlook of virus and this stigma is affecting the Chinese company's sales performance and the implication is huge in terms of financial loss. The responses of 83 respondents shows that $98.8 \%$ have purchased one product or the other online while only $1.2 \%$ did not have any online experience. There are different online platforms in Mexico and SHEIN is one of the popular online platforms because of its low-price strategy. Among the participants that have experienced online shopping, 50.6\% belong to SHEIN while 49.4\% pitched their tents with other online shopping platforms such as Ali Express, Amazon, Mercadolibre and Privalia. Regarding the frequency of online purchase, $39.8 \%$ purchased online monthly, $39.8 \%$ between 2 to 3 times, $16.9 \%$ between 4 to 5 times while $3.6 \%$ purchased more than 6 times. SHEIN specialize in selling different clothing materials and the respondents experience in purchasing clothing materials from SHEIN is as follows: $23.3 \%$ have purchased clothing materials for only 1 time, $46.5 \%$ for 2 to 3 times, $27.9 \%$ for 4 to 5 times and $2.3 \%$ for more than 6 times.

Concerning the participants responses to five Likert Scale questions, $49.4 \%$ have positive perception about SHEIN Brand, 19.2\% have negative perception while 31.3\% were neutral about SHEIN Brand perception in Mexico. Regarding question on how COVID-19 affect SHEIN sales in Mexico, 56.6\% believed that COVID-19 affects the SHEIN sales in Mexico, 20.4\% did not believe that COVID-19 affect SHEIN sales in Mexico, while $22.9 \%$ were neutral about the effect of COVID-19 on SHEIN sales. Concerning question about customers churning from SHEIN due to stigmatization, $47 \%$ shows their intention to stop shopping at SHEIN, $32.5 \%$ wish to continue despite the stigma while $20.5 \%$ were neutral about their decision stop or continue.

The study carried out a correlation analysis between four variables regarding the SHEIN perception regarding COVID-19, SHEIN clothes likeness, drop in SHEIN sales due to the COVID-19 perception and intention to stop shopping at SHEIN online store. The results show a moderate correlation (Pokrzywinski, et al. 2020) between SHEIN perception of COVID-19 and drop in SHEIN sales $r=-0.62, n=83, p<.001$. Also, there is a moderate correlation coefficient between the intention of the buyers to stop buying at SHEIN online store and customers likeness for SHEIN clothes $\mathrm{r}=-0.34, \mathrm{n}=83, \mathrm{p}<.001$. The study had a negative correlation which indicate that the higher the SHEIN perception of the COVID-19, the lower the SHEIN sales and the higher the intention of the SHEIN buyers to stop shopping the lower their likeness for the SHEIN clothes (Table 1).

The study used three independent variables (SHEIN clothes likeness, SHEIN drop in sales, intention to stop shopping at SHEIN) and one dependent variable (SHEIN perception of COVID-19) for ANOVA analysis. Out of the three predictors, only SHEIN drop in sales predicts the SHEIN perception of COVID-19. SHEIN Clothes likeness $\mathrm{F}(4,78)=.235, \mathrm{p}=>0.05$, SHEIN sales $\mathrm{F}(4,78)=15.55, \mathrm{p}=<0.01$, Stop SHEIN shopping F $(4,78)$ $=1.408, \mathrm{p}=>0.05$. SHEIN drop in sales is the determinant of SHEIN perception of COVID-19 while SHEIN Clothes likeness and Stop SHEIN shopping are not the determinants of SHEIN perception of COVID-19. 


\section{DISCUSSION}

This study sheds light on how COVID-19 pandemic and its associated stigmatization is affecting businesses particularly, SHEIN in Mexico. Table 1 presents the brand perception, sales performance, and customer shunning of SHEIN before and during the COVID-19 pandemic. Obviously, due to the stigma associated with the disease the brand perception of SHEIN dropped to $49.4 \%$. The result suggests that the emergence of COVID-19 presents a change for SHIEN's brand hence the reduction in customer-use, trust, security, reputation, and word of mouth recommendation. Similarly, $56.6 \%$ of the respondents reveal that the COVID-19 pandemic and its accompanying stigma has negative impact on SHEIN's sales thereby affecting income revenue, profit margins, overheads, and jeopardize the survival of SHEIN. Undoubtedly, because of the reduction in sales, SHEIN will experience negative cash flow and huge impact on operating and administrative cost, which has high possibility of triggering lay-off of workers. As the stigma of COVID-19 continues ravaging several businesses, $47 \%$ of loyal customers of SHEIN indicate their intention of shunning, while $32.5 \%$ suggest continuing patronizing SHEIN. Additionally, 20.5\% of SHEIN's loyal customers remain neutral or undecided whether to continue with SHEIN. This study established a curvilinear relationship between COVID-19 and economic activities and this relationship shows a pattern of increasing unstable economic activities with increasing COVID-19 burden. Besides, this study confirmed the negative impact of stigmatization on economic activities of e-commerce through brand perception, low sales performance and customers churning intention. The insights draw from this study show a direction to how to overcome this lingering pandemic through theoretical and managerial implication.

\section{THEORETICAL AND MANAGERIAL CONTRIBUTION}

\subsection{Theoretical Contribution}

Goffman's theory of social stigma posits that a stigma is a discredited reputation (Goffman 1963) and after 50 years Bos, Pryor, Reeder and Stutterheim (2013) expanded the work of Goffman's on spoiled identity and showcased Pryor and Reeder (2011) model of four types of stigma, that is, structural, public, association and self-stigma which indicates stigma impact on the society, interpersonal and individual levels. This study applied the Goffman's theory of social stigma based on interdisciplinary approach as proposed by Pryor et al. (2013). This study contributes to the theory of stigma in two ways.

First, the study discovered a gap in the model of Pryor and Reeder (2011) in the context of organizational stigma and introduced organization dent reputation as an outcome of structural, public, association, or self-stigma. This study argues that are different sources of stigma that can affect organization reputation. In the case of SHEIN, Corona virus originated from China triggered discredit for Chinese companies in diaspora. The ongoing stigma contention against e-commerce online platform established the fact that company's reputation with the public is very crucial (Olaleye, Salo and Ukpabi 2018a).

Second, this study also introduced organization response to stigma to the existing model of Pryor et al. (2013). Stigmatization has a beginning, and the beginning may be unnoticed if the company did not have a very sensitive public relation. According to Olaleye, Sanusi and Salo (2018b) online reputation management is an extension of conventional public relations. The negative impact of company stigma is to diminish the company's growth in all ramification and the prompt response of the companies to launder this dent image will determine the end results. The stigma model is incomplete without the prompt company response. This research built on the existing stigma studies and shows how stigma of any kind can dent the organization reputation and how important for organization to respond promptly and contributes to the literature of stigma theoretically.

\subsection{Managerial Contribution}

Managerially, this study opines that the best way to reduce SHEIN stigmatization is by generating an idea of solidarity and empathy, where customers are the protagonists of the story in a scenario where they meet many more people and share their shopping experience with happiness. The protagonists should be able to say: 
"I have bought something in SHEIN, and I am looking forward to it, I will surely love it", even in times of adversity. As the promotion of SHEIN products, this research proposes to communicate to the public around SHEIN customers segment with a short video of 40 seconds. The video should go viral on the social media platforms and SHEIN website. The proposed video should disseminate the value proposition of SHEIN brand. SEHIN managers should also transmit a message of solidarity and moral support to people who are quarantine due to the pandemic of COVID-19 in Mexico. A professional video script should be crafted, rehearsed before final production. Possibly, celebrity or opinion leaders should be involved in SHEIN reputation laundering. This image laundering campaign should run for two months consistently between 40 seconds and 1 minute at a stretch. The evaluation of this campaign should take place against the budget for Facebook, YouTube, and the results of the organic strategy on Tweeter. This managerial contribution will help SHEIN to regain their lost reputation and other companies that suffers from COVID-19 stigmatization.

\section{LIMITATION AND FUTURE SUGGESTIONS}

This study is a response to stigmatization of a case company in Mexico and the study is limited to the student sample nevertheless, the future research can work on this foundational result to implement a diversified sample in Latin America on stigmatization of online stores. It is recommended that the new proposed stigma model be tested across nations, especially in the developed countries.

\section{ACKNOWLEDGEMENT}

We acknowledge the effort of HÉCTOR B. BENÍTEZ, MARIA JOSE DORANTES RODRIGUEZ, JOSÉ MANUEL FERNÁNDEZ GONZÁLEZ, BADIR SÁNCHEZ BRITO, ALAM JAMIL RAMOS to collect the data for this study. They are bachelor students of Strategic Marketing and Consulting at Universidad de las Americas Puebla (UDLAP), Mexico between January to May 2020. This is a requirement of their Capstone project.

\section{REFERENCES}

Ahmad, M. (2018). Online shopping behavior among university students: Case study of Must University. Advances in Social Sciences Research Journal, 5(4)

Allport, G. W., Clark, K., \& Pettigrew, T. (1954). The nature of prejudice

Andrade, G. (2020). Medical conspiracy theories: cognitive science and implications for ethics. Medicine, Health Care, and Philosophy, 1.

Ayittey FK, Ayittey MK, Chiwero NB, Kamasah JS \& Dzuvor, C: Economic impacts of Wuhan 2019 nCoV on China and the world. J Med Virol 2020; 92:473-75.

Bartneck, C., Duenser, A., Moltchanova, E., \& Zawieska, K. (2015). Comparing the similarity of responses received from studies in Amazon's Mechanical Turk to studies conducted online and with direct recruitment. PloS one, 10(4), e0121595.

Bashir, S., Zeeshan, Muhammad., Sabbar, Sabbardahham., Hussain, R. I., \& Sarki, I. H. (2013). Impact of cultural values and lifestyle on impulse buying behavior: a case study of Pakistan. International Review of Management and Business Research, 2(1), 193.

Bos, A. E., Pryor, J. B., Reeder, G. D., \& Stutterheim, S. E. (2013). Stigma: Advances in theory and research. Basic and applied social psychology, 35(1), 1-9.

Carlsson-Szlezak P, Reeves M \& Swartz P: Understanding the economic shock of coronavirus. Harvard Business Review, March 27, 2020. https://hbr.org/2020/03/ understanding-the-economic-shock-of-coronavirus.

Correia de Barros, A., Duarte, C., \& Cruz, J. B. (2011). The influence of context on product judgement-Presenting assistive products as consumer goods. International Journal of Design, 5(3), 99-112

Devers, C. E., Dewett, T., \& Belsito, C. A. (2005). Falling out of favor: illegitimacy, social control, and the process of organizational stigmatization. In Academy of Management Proceedings (Vol. 2005, No. 1, pp. D1-D5). Briarcliff Manor, NY 10510: Academy of Management. 
Estadilla, L. S. (2020). The Economics of COVID-19 in the Philippines. Eubios Journal of Asian and International Bioethics, 30(9), 178.

Faqih, K. M., \& Jaradat, M. I. R. M. (2015). Assessing the moderating effect of gender differences and individualism-collectivism at individual-level on the adoption of mobile commerce technology: TAM3 perspective. Journal of Retailing and Consumer Services, 22, 37-52.

Goffman, Erving (1963). Stigma: Notes on the Management of Spoiled Identity. Prentice Hall. ISBN 978-0-671-62244-2.

Meisenbach, R. J. (2010). Stigma management communication: A theory and agenda for applied research on how individuals manage moments of stigmatized identity. Journal of Applied Communication Research, 38(3), 268-292.

Moufakkir, O. (2015). The stigmatized tourist. Annals of Tourism Research, 53, 17-30.

Olaleye, S. A., Salo, J., \& Ukpabi, D. C. (2018a). The Role of Reputation on Trust and Loyalty: A Cross-Cultural Analysis of Tablet E-Tailing. International Journal of E-Business Research (IJEBR), 14(2), 61-75.

Olaleye, S. A., Sanusi, I. T., \& Salo, J. (2018b). Sentiment analysis of social commerce: a harbinger of online reputation management. International Journal of Electronic Business, 14(2), 85-102.

Olaleye, S. A., Salo, J., Sanusi, I. T., \& Okunoye, A. O. (2018). Retailing Mobile App Usefulness: Customer Perception of Performance, Trust and Tension Free. International Journal of E-Services and Mobile Applications (IJESMA), 10(4), $1-17$.

O'Sullivan M: Fast recovery or great depression? Three scenarios for the coronavirus economic crisis. Forbes, March 29, 2020. https://www.forbes.com/sites/mikeosullivan/2020/03/29/fast recovery-or-great-depression-three-scenarios-forthecoronavirus-economic crisis/\#15fdd8526b33.

Parker, R., \& Aggleton, P. (2003). HIV and AIDS-related stigma and discrimination: a conceptual framework and implications for action. Social science \& medicine, 57(1), 13-24.

Pokrzywinski, R., Soliman, A. M., Surrey, E., Snabes, M. C., \& Coyne, K. S. (2020). Psychometric assessment of the PROMIS Fatigue Short Form 6a in women with moderate-to-severe endometriosis-associated pain. Journal of PatientReported Outcomes, 4(1), 1-10.

Pryor, J. B., \& Reeder, G. D. (2011). HIV-related stigma. HIV/AIDS in the Post-HAART Era: manifestations, treatment, and Epidemiology, 790-806.

Stokes, C., \& Senkbeil, J. C. (2017). Facebook and Twitter, communication and shelter, and the 2011 Tuscaloosa tornado. Disasters, 41(1), 194-208.

Stout, A., Ghosh, S., Battogtokh, Z., \& Yun, J. (2020). Track Corona. Obtenido de Latest Data: https://www.trackcorona.live/.

The Economist: Governments are still struggling to get ahead of the coronavirus. March 17, 2020. https://www.economist.com/international/2020/03/17/governments-are-still-struggling-to-get-ahead-ofthecoronavirus.

Tracey, P., \& Phillips, N. (2016). Managing the consequences of organizational stigmatization: Identity work in a social enterprise. Academy of Management Journal, 59(3), 740-765.

Trautmann S, Rehm J \& Wittchen HU: The economic costs of mental disorders. EMBO Rep 2016; 17:1245-9.

UNICEF, (2020). Social Stigma associated with COVID-19. Available online from: https://www.unicef.org/media/65931/file/Social\%20stigma\%20associated\%20with\%20the\%20coronavirus\%20diseas e\%202019\%20(COVID-19).pdf. Access on: 26.04.2020.

Weller C: What we know about the economic impact of the coronavirus and how that should guide policy. Forbes, March 19, 2020. https://www.forbes.com/sites/ christianweller/2020/03/19/what-we-know-about-theeconomic-impact-of-thecoronavirus-and-how-thatshould-guide-policy/\#4175d6c0375f. 